\section{'UF Multi-flora Peach' and 'UF Multi-flora Pink Frost': Multi-flora Gerbera Cultivars for Landscapes and Large Pots}

\author{
Zhanao Deng and Brent K. Harbaugh \\ University of Florida, Institute of Food and Agricultural Sciences, Environmental \\ Horticulture Department, Gulf Coast Research and Education Center, 14625 \\ CR 672, Wimauma, FL 33598
}

Additional index words. Gerbera hybrida, Gerbera jamesonii, Gerbera viridifolia, Asteraceae, beeding plant, plant breeding

Gerbera (Asteraceae Dumont) is an important floricultural crop in the United States and worldwide (Rogers and Tjia, 1990). Commercial production of this plant began in Europe at the turn of the 20th century and in North America in the early 1920s (Rogers and Tjia, 1990). The history of gerbera breeding can be traced back to the late 19th century when Richard Lynch made the cross between Gerbera jamesonii Bolus ex Hooker f. and G. viridifolia (DC.) Schultz-Bip. in the Royal Botanical Garden at Kew, England. This was shortly after G. jamesonii was discovered in South Africa and recognized in England in 1889 (Tourjee et al., 1994). Most of the current commercially grown cultivars are from this cross and therefore, they have been given a provisional designation G. hybrida (Bremer, 1994; Hansen, 1999; Kloos et al., 2004).

Gerberas can be propagated vegetatively and sexually (Rogers and Tijia, 1990). Gerbera's crowns are composed of compact rhizomes that bear vegetative buds. Division and cultivation of these rhizomes can result in multiplication of gerbera plants. New plants in the range of 10 to 20 , up to 40 , could be obtained from a single mature plant through rhizome division. During crown division, pathogens could be carried from one generation to the next on plantlets. One of the pathogens frequently carried during crown division is Phytophthora cryptogea, which causes crown rot or root rot in gerberas. This method of propagation became of limited use when tissue culture and regeneration of gerberas became possible in the 1970s. Tissue culture-derived liners offer a high level of uniformity in flower color, form, and plant growth habit. In addition, these liners are generally of excellent vigor and free of pathogens including Phytophthora (Anonymous, 2005; Behnke, 1984; Murashige et al., 1974). Thus tissue culture has been used widely in gerbera propagation.

Received for publication 19 Dec. 2005. Accepted for publication 25 Jan. 2006. This research was supported by the Florida Agricultural Expt. Station, and approved for publication. We thank Richard Kelly, Nancy West, Joyce Jones, and Gail Bowman for their excellent technical support, and Sunshine State Carnations, Inc., for donation of gerbera seeds and financial support.
Extensive gerbera breeding has been conducted in the Netherlands, United States of America, Demark, Germany, Israel, Japan, ditionally have targeted development of new or improved cultivars for production of cut gerbera for use as small potted plants (10- to 12.7-cm-diameter pots) has increased dramatically in the last decade.

Interest in using gerberas for the flower garden or landscape and in large patio containers has increased in recent years. Yet, breeders only have begun to target development of plants for this market. Landscapers have had to use cultivars that are bred as cut flowers or pot plants, and these types often do not perform ideally in the landscape. Our observations and experience indicate that a number of vegetative and floral characteristics are necessary, for gerbera plants to survive and perform well in the landscape, including adequate plant vigor and size, appropriate peduncle heights, and adequate disease resistance. 'UF Multi-flora Peach' (Fig. 1) and 'UF Multi-flora Pink Frost' (Fig. 2) have been selected specifically for garden use. Both cultivars are very vigorous and produce large plants with a continuous supply of flowers in the garden. Although

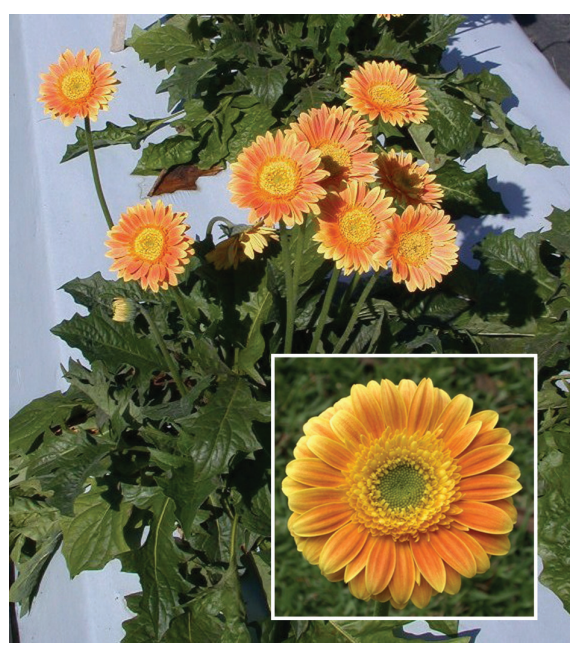

Fig. 1. Flowers and plants of 'UF Multi-flora Peach' gerbera grown in a raised bed. and other countries. Breeding objectives traflowers (Rogers and Tjia, 1990), but breeding their flowers are not large, their plants display multiple flowers and buds resulting in plants with as much color as plants with larger, but fewer flowers. In addition, 'UF Multi-flora Peach' has shown intermediate powdery mildew resistance.

\section{Origin}

'UF Multi-flora Peach' and 'UF Multi-flora Pink Frost' were selected from a population of 1500 seedlings grown from seeds donated to the University of Florida by Ole Nissen, Sunshine State Carnations, Inc. (Hobe Sound, Fla.). Parents were unknown but were the result of 30 years of gerbera breeding in southern Florida.

\section{Description}

Descriptions of color (e.g., RHS 200B) for plant parts were based on comparison with the Royal Horticultural Society Colour Chart (Royal Horticultural Society, 1986). Plants used for describing color were grown in 20$\mathrm{cm}$ containers in a $15 \%$ shaded greenhouse and were 4 months old produced from tissue culture liners.

Mature plants of 'UF Multi-flora Peach' grown in ground beds for 3 months were 74 $\mathrm{cm}$ wide (Table 1). The leaves were simple, pinnately lobed, with deep lobes on the base, medium in the central part and slight at the apice. The upper surface was yellow-green (RHS 147A). The lower surface was a slightly lighter yellow green (RHS 147B). The flowers were semi-double and $8.5 \mathrm{~cm}$ in diameter. The peduncle height ranged from 30 to $45 \mathrm{~cm}$ with an average of $36 \mathrm{~cm}$ on immature flowers and from 39 to $49 \mathrm{~cm}$ with an average of $48 \mathrm{~cm}$ on mature flowers. Peduncles were yellow-green (RHS 145B) and involucres was green (RHS 137B). The disc florets were a bright dark yellow (RHS 12C) and the inflorescence center light yellow (RHS 10A). The upper surface of the outer ray florets was orange-red (RHS 32A) diffusing into yellow (RHS 7D) toward the tip. The lower surface was yellow-orange (RHS 14C).

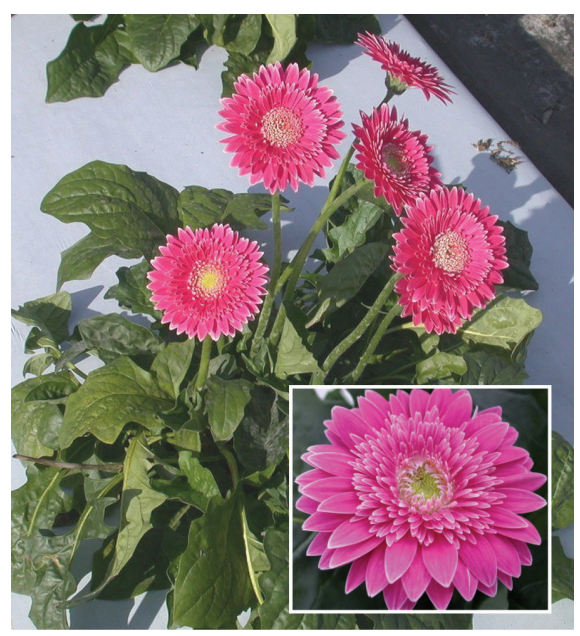

Fig. 2. Flowers and plants of 'UF Multi-flora Pink Frost' gerbera grown in a raised bed. 
Table 1. Characteristics, plant quality and powdery mildew resistance of three asexually propagated multi-floral gerberas ('Louisville', 'UF Multi-flora Peach' and 'UF Multi-flora Pink Frost') and one seed-propagated gerbera ('Revolution Mix') grown in 18-cm (2.8-L) pots or in ground beds at Bradenton, Fla.

\begin{tabular}{|c|c|c|c|c|c|c|c|c|c|c|}
\hline Cultivar & \multicolumn{2}{|c|}{ Total flowers ${ }^{2}$} & \multicolumn{2}{|c|}{ Peduncle ht $(\mathrm{cm})^{y}$} & $\begin{array}{c}\text { Flower } \\
\text { diam } \\
(\mathrm{cm})\end{array}$ & $\begin{array}{c}\text { Plant } \\
\text { width } \\
(\mathrm{cm})\end{array}$ & \multicolumn{2}{|c|}{ Plant quality ${ }^{\mathrm{x}}$} & \multicolumn{2}{|c|}{ Powdery mildew ${ }^{\mathrm{w}}$} \\
\hline Louisville & 3 & 11 & 49 & 57 & 9.4 & 77 & 2.0 & 2.2 & 9.8 & 9.8 \\
\hline Revolution Mix & 10 & 13 & 18 & 25 & 9.0 & 53 & 1.0 & 2.2 & 10.0 & 10.0 \\
\hline $\operatorname{LSD}(0.05)$ & 1.2 & 3.8 & 4.2 & 3.1 & 0.6 & 5.9 & 0.9 & 0.9 & 1.4 & 0.5 \\
\hline
\end{tabular}

${ }^{z}$ Total flowers: pot $=$ the number of flowers produced per plant from planting plugs into 18-cm pots on 14 June until plants were transplanted into ground beds on 8 Sept.; bed = the number of flowers produced in beds from 8 Sept. until termination of the experiment 24 Nov.

yPeduncle height: immature $=$ the height of the peduncle from the base of the plant to the base of the inflorescence when a flower had just opened; mature $=$ the peduncle height when the flower was near senescence.

${ }^{x}$ Plant quality ratings were subjective ratings on the plant foliage: $1=$ severe damage, all leaves infected with diseases and plants near death; $3=$ some leaves infected with diseases on the plant but the plant would still be acceptable to a gardener; $5=$ little or no visible evidence of disease infection, all leaves appearing healthy.

${ }^{\text {w }}$ Severity of powdery mildew was rated on a scale of 1 to 10 as described by Hausbeck et al. (2002): $1=$ no disease, $2=$ trace to $10 \%$ infection, $3=10 \%$ to $20 \%, 4$ $=20 \%$ to $30 \%, 5=30 \%$ to $40 \%, 6=40 \%$ to $50 \%, 7=50 \%$ to $60 \%, 8=60 \%$ to $70 \%, 9=70 \%$ to $80 \%$, and $10=80 \%$ to $100 \%$ infected with powdery mildew.

Mature plants of 'UF Multi-flora Pink Frost' grown in ground beds for 3 months were 62 $\mathrm{cm}$ wide (Table 1). The leaves were simple, pinnately lobed, with medium deep lobes on the base and very shallow lobbing in the central part and the apice. The upper surface was yellow-green (RHS 147A). The lower surface was a slightly lighter yellow-green (RHS 147B). The flowers were semi-double and $8.6-\mathrm{cm}$ in diameter. The peduncle height ranged from 29 to $41 \mathrm{~cm}$ with an average of 35 $\mathrm{cm}$ on immature flowers and from 40 to $44 \mathrm{~cm}$ with an average of $42 \mathrm{~cm}$ on mature flowers. Peduncles were yellow-green (RHS 145B) and the involucre was green (RHS 137B). The disc florets were similar in color to the ray florets and the inflorescence center was yellow (RHS 3B). The upper surface of the outer ray florets was red-purple at the base, became lighter red purple near the center (RHS 63B), and diffused into white (RHS 155D) toward the tip. The lower surface was predominantly white (RHS $155 \mathrm{C}$ ), but with some red-purple (RHS 64D).

\section{Performance}

We compared growth and flowering of ' $U F$ Multi-flora Peach' and 'UF Multi-flora Pink Frost' to 'Revolution Formula Mix' and 'Louisville'. We chose 'Revolution Formula Mix' because it is a popular seed propagated cultivar known for early production of many flowers. It is typically grown for market in $12.7-\mathrm{cm}$ containers. We chose 'Louisville' because it is a multi-floral cut-flower type that also is used in the landscape. Standard cut-flowers produce flowers 10 to $14 \mathrm{~cm}$ in diameter, whereas seed and multi-floral types are smaller, generally 7 to $9 \mathrm{~cm}$ in diameter. 'UF Multi-flora Peach' and 'UF Multi-flora Pink Frost' have multi-floral size flowers. Plants were evaluated in pots to determine flowering potential before marketing. Early flowering in pots is an important characteristic even for garden types of gerbera since they are sold in flower to be transplanted into ground beds later.

Tissue culture liners or seeded plugs ('Revolution Mix' only) were transplanted into $18-\mathrm{cm}$ pots on 14 June 2004 and grown in a glass greenhouse with about $30 \%$ shade. A peat-vermiculite mix (Vergo Container MixA, Verlite Co., Tampa, Fla.) was used and plants top-dressed with Osmocote $18 \mathrm{~N}-2.6 \mathrm{P}-10 \mathrm{~K}$ controlled release fertilizer (Scotts Co., Marysville, Ohio) at $6 \mathrm{~g} /$ pot. The number of flowers produced per potted plant was recorded through 8 Sept. when plants were transplanted into ground beds. All cultivars were flowering and their sizes were typical of plants marketed commercially. The growing area was shaded with $30 \%$ polypropylene shade cloth. The soil was an EauGallie fine sand with about $1 \%$ organic matter and a $\mathrm{pH}$ of 6.2 . Plants were grown in a plastic-mulched raised-bed system maintaining a constant water table with sub irrigation (Geraldson et. al, 1965). The beds were $91 \mathrm{~cm}$ wide and $20 \mathrm{~cm}$ high

with plants spaced $38 \mathrm{~cm}$ apart. Osmocote $15 \mathrm{~N}-3.9 \mathrm{P}-10 \mathrm{~K}$ controlled release fertilizer (Scotts Co., Marysville, Ohio) was applied to the bed surface around each plant at $24 \mathrm{~g} /$ plant. The number of flowers that opened each week was recorded weekly, and plant and flower characteristics measured 24 Nov. On 20 Oct. and 3 Nov., plants were rated for plant (leaf) quality on a 1 to 5 scale: $1=$ plants severely infected with diseases, most leaves exhibiting visible symptoms and many dead leaves, $3=$ plants with moderate disease infection with only a few leaves with visible infection and some leaf discoloration, and $5=$ little or no visible infection, no leaf discoloration, and leaves appearing very healthy. On 23 Oct. and 23 Nov., 2004, the severity of powdery

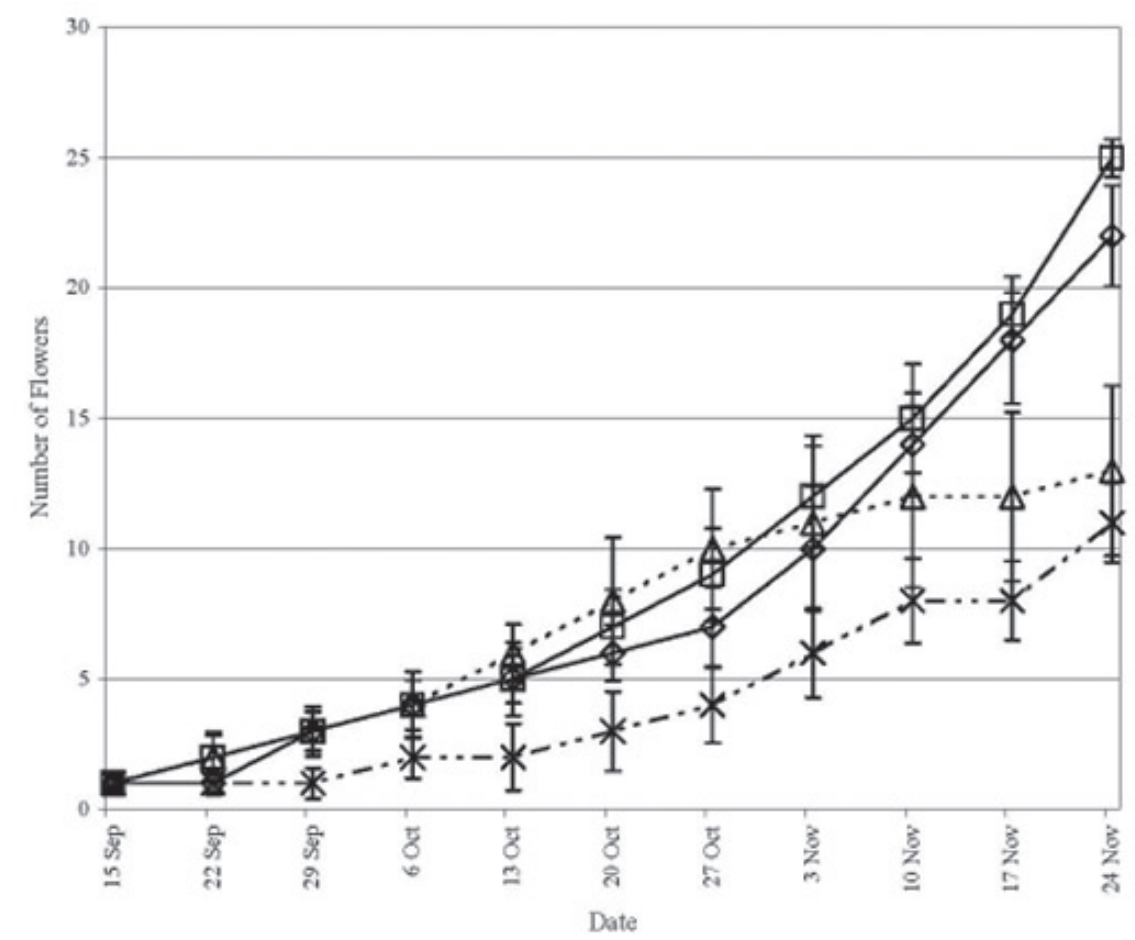

Fig. 3. Cumulative number of flowers produced per plant of four cultivars, 'UF Multi-flora Peach' $(\square)$, 'UF Multi-flora Pink Frost' $(\diamond)$, 'Louisville' $(\Delta)$, and 'Revolution Formula Mix' $(\times)$ over 10 weeks from 15 Sept. to 24 Nov. 2004 in flower beds at Bradenton, Fla. Each value represents the mean $( \pm S D)$ of four replications with three plants per replication. 
mildew (Erysiphe cichoracearum DC.)(Chase, 2001; Hausbeck et al., 2002) on leaves was assessed using a scale of 1 to 10 as described by Hausbeck et al. (2002).

'Revolution Formula Mix' produced significantly more flowers in pots (average of 10 flowers/plant) than the other cultivars (three to four flowers per plant) (Table 1). After transplanting into the field, 'UF Multiflora Peach' and 'UF Multi-flora Pink Frost' produced nearly twice as many flowers (22 to $25 /$ plant) by the end of the test than the other cultivars (11 to 13 flowers/plant). We believe this attribute, continual flowering over a long period, is essential if the cultivar is to be successful in the garden or landscape. 'Revolution Mix' produced few new flowers after 3 Nov., while 'UF Multi-flora Peach' and 'UF Multiflora Pink Frost' continued to produce many flowers late in the season (Fig. 3).

Plant width was greatest for 'UF Multi-flora Peach' and 'Louisville' and intermediate for 'UF Multi-flora Pink Frost'. Seed propagated varieties often lack vigor and do not grow to adequate sizes in the garden or big containers (Channel, 2005). This was true with 'Revolution Mix', which reached only about $75 \%$ of the plant width (or about $50 \%$ of the plantcovered area) of 'UF Multi-flora Peach' and 'Louisville'.

'UF Multi-flora Peach'was rated the highest (4.8 and 5.0) in plant (leaf) quality, followed by 'Multi-flora Frost Pink' (4.2 and 3.0). Plants of 'Louisville' and 'Revolution Mix' performed poorly ( 1 to 2.2 ) in both ratings
(23 Oct. and 3 Nov. 2004). This difference in plant performance was, to a major extent, due to their resistance level to powdery mildew. 'UF Multi-flora Peach' had the lowest powdery mildew severity ratings (3.2 and 3.4) at both rating periods, thus the greatest level of resistance. 'UF Multi-flora Pink Frost' had higher powdery mildew severity ratings and was more susceptible than 'UF Multi-flora Peach', but still less susceptible than 'Louisville' or 'Revolution Mix', which had almost $100 \%$ of their leaf areas infected with powdery mildew and reached a score of 10 .

In summary, 'UF Multi-flora Peach' and 'UF Multi-flora Pink Frost' are intended for use in the landscape or for large containers. They produce many flowers over an extended period making them ideal for garden plants.

\section{Availability}

Patents will be applied for 'UF Multi-flora Peach' and 'UF Multi-flora Pink Frost' by the Florida Agricultural Experiment Station. Production of this cultivar is to be with a licensing agreement with the Florida Foundation Seed Producers, Inc., P.O. Box 309, Greenwood, FL 32443. Information on availability and propagation agreements can be obtained from the Florida Foundation Seed Producers, Inc.

\section{Literature Cited}

Anonymous. 2005. History of Gerbera jamesonii. Florist de Kwakel B.V.12 May 2005.http://www. gerbera.com/gerbera/news/newsvast $1 . h t m 1 /$.
Behnke, M. 1984. Gerbera production. Grower Talks 47:94-97.

Bremer, K. 1994. Asteraceae, cladistics and classification. Timber Press, Portland, Ore.

Channel, C. 2005. Gerbera trials rate plants. GM Pro 25:30-31.

Chase, A.R. 2001. 2001 Update on powdery mildew control. Greenhouse Product News 11(7):44-46.

Geraldson, C.M.,A.J. Overman, and J.P. Jones. 1965. Combination of high analysis fertilizers, plastic mulch and fumigation for tomato production on old agricultural land. Proc. Soil Crop Sci. Soc. Fla. 25:18-24.

Hansen, H.V. 1999. A story of the cultivated Gerbera. The New Plantsman (Royal Hort. Soc.) 6:85-95.

Hausbeck, M.K., W.R. Quackenbush, and N.A. Werner. 2002. Evaluation of fungicides for control of powdery mildew of transvaal daisy, 2001. F\&N Tests 57:OT27.

Hausbeck, M.K., W.R. Quackenbush, and S.D. Linderman. 2002. Evaluation of cultivars of African daisy for resistance to powdery mildew, 2002. B\&C Tests 18:00004.

Kloos, W.E., C.G. George, and L.K. Sorge. 2004. Inheritance of flower types of Gerbera hybrida. J. Amer. Soc. Hort. Sci. 129:802-810.

Murashige, T., M. Serpa, and J.B. Jones. 1974. Clonal multiplication of gerbera through tissue culture. HortScience 9:175-180.

Rogers, M.N. and B.O. Tjia. 1990. Gerbera production for cut flowers and pot plants. Timber Press, Portland, Ore.

Royal Horticultural Society. 1986. Royal Horticultural Society colour chart. Royal Hort. Soc., London.

Tourjee, K.R., J. Harding, and T.G. Byrne. 1994. Early development of gerbera as a floricultural crop. HortTechnology 4:34-40. 